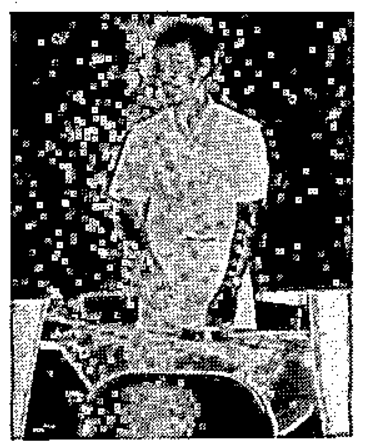

\title{
AGENDA DAN STRATEGI PEMBANGUNAN HUKUM DALAM PJP II
}

\author{
Oleh Salman withan
}

Strategi penting dalam mengantisipasi hukum pada PJPT II salah satunya adalah dengan merevisi dan mengganti sebagian besar hukum kolonial yang masih berlaku. Hal ini dilakukan bukan hanya karena alasan politik untuk membayar hutang sejarah terhadap cita-cita proklamasi kemerdekaan. Tapi juga karena hukum peninggalan kolonial itu sudah ketinggalan jaman, demikian tulis Salman. Lebih jauh memasuki PJPT II berbagai masalah sosial barupun muncul dan hal itu tentu perlu alternatif.

\section{Pendahuluan}

Bangsa Indonesia memasuki periode Pembangunan Jangka Panjang (PJP) II yang terkenal dengan sebutan era tinggal landas terhitung sejak 1 April 1994. Era tinggal landas ini merupakan fase yang cukup penting dalam proses pembangunan bangsa karena menyangkut masa persiapan menuju era industrialisasi.

Dalam PJP II dinamika pembangunan akan semakin tinggi sejalan dengan makin meningkatnya program-program pembangunan di segala bidang. Dinamika pembangunan yang begitu tinggi akan mendorong proses perubahan sosial bergerak semakin cepat, apalagi dengan makin kuatnya liberalisme ekonomi dalam negeri, dan berkembangnya arus globalisasi dalam hubungan antar negara.
Sebagai akibatnya berbagai persoalan sosial baru yang lebih kompleks akan muncul dalam kehidupan masyarakat. Masalahmasalah baru itu memerlukan pengaturan hukum agar ada kepastian hukum dalam melakukan hubungan sosial sehingga tercipta ketertiban dan ketentraman dalam kehidupan bermasyarakat. Dengan demikian pembangunan hukum akan menjadi semakin kompleks.

PJP II merupakan kesinambungan PJP I yang baru saja kita selesaikan. Oleh karena ițu, program-program pembangunan dalam PJP II bukan hanya harus mampu menjaga kesinambungan kemajuan-kemajuan yang telah di capai dalam PJP I, tapi juga harus dapat memecahkan ekses-ekses (dampak) negatif yang timbul selama PJP I. .

Pada masa PJP I berbagai kemajuan telah berhasil diraịh dalam berbagai sektor pembanguan. Kemajuan-kemajuan tersebut 
meliputi keberhasilan program swasembada beras, pertumbuhan ekonomi, pembangunan kesehatan, pemerataan pendidikan, kependudukan, dan penyediaan prasarana umum.

Keberhasilan program swasembada beras pada pertengahan 1980-an merupakan prestasi yang cukup mengesankan, karena pada akhir tahun 1960-an Indonesia merupakan negara pengimpor beras terbesar di dunia. Keberhasilan swasembada beras ini ternyata belum dapat dinikmati oleh para petani, karena perkembangan harga bahan pokok ini jauh berada di bawah peningkatan harga barang-barang produksi lainnya.

Pertumbuhan ekonomi Indonesia selama PJP I mencapai rata-rata lebih dari 6 persen per tahun. Menurut Bank Dunia prestasi ini merupakan salah satu di antara 7 keajaiban pertumbuhan ekonomi dunia. Prestasi ini berhasil mengangkat posisi Indonesia dari negara berpendapatan rendah menjadi berpendapatan menengah.

Pertumbuhan ekonomi yang cukup tinggi tersebut mampu meningkatkan pendapatan per kapita penduduk, dan mengurangi jumlah penduduk miskin. Dengan menggunakan garis kemiskinan yang ditetapkan Bank Dunia, terdapat penurunan tajam dari bagian penduduk yang digolongkan miskin, terutama di Jawa. Bagian penduduk pedesaan yang miskin menurun dari 50 persen tahun 1970 menjadi 30 persen pada tabun 1976 (H.W. Arndt:1983:53), dan menjadi 15 persen pada akhir 1992 (BPS:1993).

Namun ada dampak negatif yang menyertai pertumbuhan ekonomi ini, yaitu ketidakmerataan yang makin meningkat, terutama daerah perkotaan Jawa. Di samping itu, timbul pula disparitas yang semakin melebar antara daerah perkotaan dan daerah pedesaan. Dengan kata lain, ketimpangan pendapatan antara kaya dan miskin makin meluas (H.W. Amdt: 1-53). Fenomena konglomerasi yang muncul sejak awal tahun 1990-an merupakan potret nyata penumpukan kekayaan pada segelintir orang.

Pembangunan kesehatan menunjukan prestasi yang menggembirakan, yang ditandai dengan meningkatnya harapan hidup (life expectation) dan penyediaan sarana kesehatan sampai ke daerah pedesaan. Hal yang sama juga terjadi pada pembangunan dalam bidang kependudukan; di mana tingkat kelahiran dapat ditekan sedemikian rupa.

Sedangkan keberhasilan pembangunan dalam bidang pendidikan terlihat dari keberhasilannya program pemerataan pendidikan, dan dicanangkan wajib belajar 9 tahun bagi selunuh warga negara. Keberhasilan programpendidikan diikuti pula oleh peningkatan pengangguran kaum terdidik dalam masyarakat.

Dampak negatif lainnya yang menyertai berbagai kemjuan dalam PJP I adalah pergeseran nilai-nilai budaya, peningkatan kejahatan, kemerosotan moral masyarakat, penyalahgunaan wewenang dan kekuasaan, dan merajalelanya korupsi dalam birokrasi.

Konsentrasi pembangunan dalam bidang ekonomi dan prasarana fisik menyebabkan sub sektor pembangunan lainnya, termasuk pembangunan hukum, menjadi agak terabaikan. Pembangunan hukum selama PJP I lebih banyak berfungsi sebagai penopang ekonomi dan keamanan, dan kurang menunjang pembangunan dalam sistem hukum sendiri. Akibatnya, pembangunan hukum tertinggal jauh dibandingkan dengan pembangunan ekonomi. Namun dalam PJP II ini ada pergeseran orientasi mengenai kebijaksanaan pembangunan hukum di negara kita.

Pembangunan hukum dijadikan sebagai bidang tersendiri dalam GBHN 1993 (Tap No. II/MPR/1993) yang mengatur Kebijaksanaan Pembangunan Jangka Panjang (PJP) II dan Kebijakasanaan Pelita VI. Dalam kebijaksanaan itu disebutkan secara eksplisit bahwa bidang hukum merupakan salah satu 
bidang (di antara tujuh bidang) sasaran pembangunan dalam PJP II.

Jika dibandingkan dengan beberapa GBHN sebelumnya, kebijaksanaan ini merupakan satu langkah yang cukup maju, karena dalam Pola Umum PJP I pembangunan hukum tidak di sebutkan secara eksplisit, hanya dimasukkan dalam kebijaksanaan dalam setiap Pelita. Disamping itu, bidang hukum bukan bidang tersendiri, melainkan bagian dari pembangunan bidang politik, aparatur negara, hukum, penerangan dan media massa, serta hubungan luar negeri.

Dengan demikian pembangunan hukum mempunyai posisi yang makin penting dalam spektrum pembangunan nasional. Artinya, hukum bukan hanya bidang yang harus dibangun dan dikembangkan, tapi juga memiliki peran strategis sebagai alat rekayasa sosial (a tool of social engeneering) untuk menompang dan memacu dinamika pembangunan san sarana pengaman ( $a$ tool of social control) terhadap hasil-hasil pembangunan yang di capai.

Kedudukan pembangunan hukum yang makin penting ini sekaligus merupakan tantangan bagi DPR, departemen kehakiman dan institusi- institusi hukum lainnya (kejaksaan, MA, dan organisasi-organisasi profesi hukum), dan fakultas hukum untuk menyelesaikan agenda permasalahan pembangunan hukum semakin banyak dan kompleks.

Untuk itu diperlukan strategi yang integratif di antara institusi-institusi hukum dan institusi-institusi terkait (misalnya dengan DPR untuk menyusun legislasi). Namun sebelum sampai pada pembahasan itu, terlebih dulu akan dikemukakan agenda permasalahan yang dihadapi dalam proses pembangunan hukum.

\section{Agenda permasalahan}

Ada beberapa masalah yang menjadi agenda pembangunan hukum dalam PJP II, namun ada empat hal yang paling menonjol, yakni masalah pembangunan legislasi (pembenatukan dan pembaruan undangundang), rendahnya kemampuan profesional dan mentalitas aparatur hukum, wibawa hukum yang makin merosot, dan ketimpangan struktur sosial ekonomi dalam masyarakat. Pembangunan legislasi nasional yang menjadi semakin kompleks karena belum terpenuhinya cita-cita konstitusional yang menghendaki pengganti hukum-hukum (undang-undang) peninggalan kolonial dengan hukum nasional, dan makin meningkatnya kebutuhan hukum masyarakat dalam proses pembangunan.

Hukum-hukum peninggalan kolonial yang belum sempat diganti masih cukup banyak. Menurut penelitian BPHN (Badan Pembinaan Hukum Nasional) ada sekitar 400 buah peraturan perundang-undangan. Sebagian di antara peraturan tersebut merupakan undang-undang kodifikasi, seperti KUHP, KUH Perdata, KUHD, yang proses penyiapan RUU-nya membutuhkan waktu cukup lama dan biaya yang cukup banyak pula.

Undang-undang itu perlu diperbaharui, bukan hanya karena alasan politik untuk membayar hutang sejarah terhadap cita-cita proklamasi kemerdekaan. Tapi juga karena alasan sosial dan kultural, dimana peraturan peninggalan kolonial itu kurang sejalan dengan pandangan hidup (Pancasila) dan nilai-nilai kulture bangsa. Di samping itu materi peraturan tersebut banyak yang tidak sesuai lagi dengan kebutuhan zaman.

Masalah-masalah sosial baru yang muncul dalam proses pembangunan menghendaki pengaturan hukum agar tercipta kepastian hukum dalam melakasanakan aktivitas sosial ekonomi masyarakat. Misalnya pengaturan hukum tentang alih teknologi, ruang angkasa, monopoli, dan sebagainya.

Agenda berikutnya yang tidak kalah kompleksnya dengan pembangunan 
legislasiadalah pengembangan sumber daya manusia aparatur hukum (mentalitas dan profesionalisme). Sumber daya manusia (SDM) mempunyai peranan penting dalam kehidupan manusia, karena kualitas SDM menentukan kemajuan dan kemuduran suatu peradaban, kemajuan dan kemunduran suatu organisasi, kemajuan dan kemunduran masyarakat, serta bangsa dan negara.

Bukan rahasia umum lagi, jika bidang profesi atau pekerjaan yang palig banyak disorot dan di kecam dalam masyarakat adalah profesi hukum. Aparat penegak hukum sebagai agen yang bertanggung jawab bagi tegaknya hukum dan keadilan dalam tatanan kehidupan sosial semakin kehilangan kredibilitas. Citra pengadilan sebagai benteng terakhir menjadi semakin redup.

Jika dikuti secara seksama isyu-isyu di seputar penegakan hukum dalam beberapa tahun terakhir, terlihat adanya kecenderungan makin merebaknya penyalahgunaan hukum dan profesi dikalangan aparat penegak hukum. Isyu-isyu yang menonjol adalah praktek dagang hukum di pengadilan, pelecehan hukum oleh aparat dan masyarakat, sogơk menyogok dalam penyelesaian dan pendeponiran perkara, dan tindakan main hakim sendiri. Isyu adanya praktek dagang hukum dan pelecehan hukum di lontarkan oleh ketua Makamah Agung (MA), Purwoto S. Gandasubrata. Karena yang mengemukakan adalah ketua MA, orang yang paling bertanggung jawab terhadap tegaknya hukum dan keadilan di negeri ini, maka kebenaran berita itu sangat layak di percaya. Hal ini menunjukan betapa runyamnya konndisi penegakan hukum kita.

Peranan pengadilan sebagai sarana untuk menegakkan hukum dan keadilan sudah bergeser menjadi ajang bisnis hukum dan keadilan. Cita-cita profesi untuk menjunjung tinggi hukum dan keadilan telah dilacurkan oleh para penegak hukum demi untuk mendapatkan

keuntungan

materi semata-mata.

Akibatnya, bukan hanya citra dan kredibilitas penegak hukum yang semakin menurun (rusak) di mata masyarakat pencari keadilan, tapi juga telah memerosotkan wibawa hukum, karena hukum dalam kenyataan sosiologis (law in action) melekat dalam perilaku aparatnya. Kredibilitas aparat penegak hukum makin menurun dan wibawa hukum yang makin mrosot tersebut menyebabkan hilangnya kepercayaan masyarakat terhadap pengadilan sebagai sarana untuk memperjuangkan dan memperoleh keadilan.

Kondisi yang memprihatinkan ini bisa terjadi terutama disebabkan oleh kurangnya profesionalisme di kalanngan penegak hukum (polisi, jaksa, pengacara, dan hakim). Kurangnya Profesionalisme terlihat dari lemahnya wawasan pemikiran dan keterampilan bekerja, rendahnya motivasi kerja, dan rusaknya moralitas personal. Di samping itu, juga dipengaruhi oleh kondisi sosiokultural yang hedonistik dan konsumeristik yang berkembang dalam masyarakat.

Dalam bidang legislatif kita juga mengalami masalah yang sama, di mana jumlah tenaga ahli perundang-undangan masih sangat terbatas, dan kualitas profesionalnya masih belum memadai. Olh karena itu tidak perlu heran, bila tertib hukum dalam peraturan perundang-undangan kita semrawut. Akibat lainnya, produktivitas lembaga pembentuk peraturan perundangundangan masih rendah.

Aparatur hukum yang duduk di birokrasi pemerintahan yang memberikan pelayanan hukum kepada masyarakat juga mempunyai kondisi yang tidak berbeda. Para birokrasi hukum ini yang seharusnya memberikan pelayanan kepada masyarakat, tidak jarang malah menjadi beban bagi masyarakat, karena 
dalam pengurusan administratif mereka sering dipungli oleh aparat tersebut.

Agenda lainnya adalah wibawa hukum yang makin merosot dalam masyarakat. Cita-cita "rule of low" yang menghendaki pengelolaan segala urusan pemerintahan dann kemasyarakatan harus berdasarkan kepada hukum, kini lebih banyak menjadi slogan belaka. Dalam prakteknya hukum seringkali dikesampingkan dan diabaikan, dan yang ditonjokan adalah "kebijkasanaan", yang pada esensinya tidak bijaksana.

Hukum tidak lagi dihargai bukan hanya oleh masyarakat, tapi juga oleh aparat penegak hukum sendiri maupun oleh penguasa negara. Dengan kata lain hukum semakin kehilangan fungsinya sebagai sarana untuk menyelesaikan konflik-konflik sosial secara adil dan manusiawi.

Indikator makin merosotnya wibawa hukum dapat dilihat dari peningkatan kuantitas dan kualitas kejahatan yang terjadi dalam masyarakat. Adanya kecenderungan sadisme dalam melakukan kejahatan telah menggerogoti kedamaian hidup masyarakat. Di kalangan remaja perkotaan mulai tumbuh budaya kekerasan, berupa perkelahian antar sekolah, dan perusakan-perusakan sarana hukum.

Indikator lainnya adalah berkembangnya kebiasaan main hakim sendiri dalam masyarakat, baik yang dilakukan kelompok masyarakat tertentu, maupun yang dilakukan oleh aparat penegak hukum sendiri, terutama oleh pihak kepolisian. Tindakan main hakim sendiri yang dilakukan masyarakat terhadap pelaku kejahatan terutama ditujukan terhadap para pencuri, dan pelaku kejahatan seksual. Sedangkan tindakan main hakim sendiri dilakukan oleh penegak hukum terhadap pelaku-pelaku kejahatan yang berasal dari kelompok masyarakat kelas bawah.

Disamping itu, ada kecenderungan dalam masyarakat untuk mencari cara-cara penyelesaian sengketa hukum di luar forum pengadilan, makin meyakinkan akan adanya kemerosotan wibawa hukum tersebut. Misalnya, penggunaan tenaga tukang pukul (gali) dalam penagihan utang-piutang atu kredit macet di antara perusahaan, dan metode ini juga dilakukan oleh sebagian pengacara.

Agenda terakhir pembangunan hukum dalam PJP II adalah kondisi ketimpangan ekonomi yang terjadi dalam masyarakat. Disparitas pendapatan antara kaya dan miskin tajam, ketimpangan ekonomi antara kota dan juga makin meluas, dan terjadinya penumpukan kekayaan pada segelintir orang.

Kondisi ini terjadi karena pembangunan ekonomi terlalu berorienasi pada pertumbuhan ekonomi, dan mengabaikan pemerataan. Ketimpangan struktur ekonomi masyarakat ini akan menimbulkan kecemburuan sosial, yang pada gilirannya dapat. merangsang konflik-konflik sosial sehingga menimbulkan disintegrasi sosial.

\section{Strategi Pendekatan}

Pembangunan hukum harus dilakukan secara sistematik. Artinya, pembangunan hukum harus dilihat sebagai bagian integral dari pembangunan nasional (bagian-bagian sebagai kesatuan). Dan pembangunan berbagai aspek sistem hukum (pembuatan aturan perundang-undangan (law making), pengembangan sumber daya manusia (human resources development), penegak hukum (law enforcement), dan pengembangan sarana dan prasarana merupakan satu kesatuan yang tidak terpisahkan pula.

Ada tiga argumentasi untuk mendukung strategi ini. Pertama, adanya dependensi yang kuat antara sektor pembangunan yang satu dengan sektor pembangunan yang lain. Misalnya, pembangunan ekonomi akan berhasil bila didukung oleh stabilitas politik dan hukum yang emansipatif terhadap pembangunan.

Kedua, pandangan kontemporer mengenai fungsi hukum dalam masyarakat lebih 
menekankan kepada peranan sebagai alat rekayasa sosial (a tool of social engeneering) untuk meraih kesejahteraan hidup bersama. Keiga, pengalaman empiris pelaksanaan pembangunan hukum yang belum terintegrasi.

Dengan pendekataan sistematik, orientasi pembangunan hukum diarahkan kepada dua sasaran, yaitu: pembangunan aspek-aspek sistem hukum dan pendayagunaan hukum dalam proses pembangunan nasional. Pembangunan aspek-aspek sistem hukum meliputi pembangunan legislasi (pembuatan dan pambaruan peraturan perundangundangan), penegembangan sumber daya manusia aparatur hukum, peningkatan efesiensi dan efektivitas penegakan hukum, dan pengembangan parasana.

Adanya kedua bidang sasaran itu terdapat hubungan resiprokal, artinya, ada hubungan pengaruh mempengaruhi di antara kedua sasaran itu. Oleh karena itu harus ada sinkroniasi antara pembangunan aspek-aspek sistem hukum dengan pendayagunaan hukum dalam proses pembangunan nasional. Dengan kata lain, pembangunan sub sektor sistem hukum dapat mendukung pendayagunaan hukum dalam pembangunan nasional, dan pendayagunaan hukum dalam pembangunan nasional jangan sampai mengorban pembangunan sub-sub sektor sistem hukum.

Pembangunan legislasi harus diarahkan untuk membentuk satu sistem hukum nasional yang sesuai dengan kharakteritik masyarakal Indonesia. Dan pembentukan sistem hukum nasional harus mengacu kepada sistem hukum yang hidup dalam masyarakat kita, di mana ada tiga sistem hukum yang berlaku, yaitu sistem hukum kontinental, sistem hukum adat, dan sistem hukum Islam.

Selama ini proses pembangunan legislasi cenderung berjalan secara sektoral. Hal itu bisa terjadi karena kita belum mempunyai politik legislasi nasional, yang mengatur kebijakan tentang kerangka dasar pembuatan undang-undang, penentuan skala prioritas perundang-undangan dan pembaruan hukum, peranan sosial hukum dalam proses pembangunan nasional, mekanisme pengajuan RUU, dan lembaga clearance house (lembaga sinkronisasi perundangundangan).

Fenomena yang muncul kepermukaan dalam proses penyusunan Undang-undang, masing-masing departemen seperti berlomba menyelesaikan pengaturan hukum yang menjadi wewenangnya, tanpa koordinasi dengan departemen lainnya. Kasus yang menimpa UU No. 14/1992 tentang Lalu Lintas dan Angkutan Jalan merupakan contoh kongkrit mengenai hal itu. Ada yang berpandangan bahwa pembangunan legislasi tidak berada dalam alur pembangunan tata (sistem) hukum nasional. Oleh karena itu sangat logis usul ketua MPR/DPR agar pemerintah dan DPR menyusun program legislasi nasional.

Untuk menyusun satu sistem hukum nasional maka perlu disusun kebijakan legislasi nasional, yang akan mengatur prinsip-prinsip legislasi, mekanisme penyusunan dan pengajuan RUU, skala prioritas perundang-undangan, dan lembaga sinkronisasi perundang- undangan (clearance house).

Karena pembentukan sistem hukum nasional tidak hanya bertumpu pada undang-undang tapi juga pada hukum adat maka harus ada sinkronisasi kebijakan antara pembentuk undang-undang dan pengembangan hukum adat. Walaupun UU merupakan tulang punggung utama dalam sistem hukum nasional, namun karena undang-undang tidak akan pernah lengkap, apalagi dalam arus perubahan sosial yang begitu pesat, maka kelemahan undang-undang tersebut akan dapat ditutupi oleh hukum adat. 
Pengembangan hukum adat harus di beri tempat yang seimbang dengan perundang-undangan, karena dalam arus perubahan yang begitu pesat UU menjadi cepat ketinggalan zaman sehingga orang beralih kepada hukum adat. Hasil penelitian Stewart Macauly menunjukan bahwa penyelesaian sengketa-sengketa bisnis lebih banyak mengacu kepada hukum kebiasaan dari pada hukum tertulis. Hukum kontrak hanya dianggap sebagai petunjuk umum (Macauly:1983:179).

Selanjutnya bagaimana kedudukan sistem hukum Islam dalam sistem hukum nasional ?. Karena sistem hukum Islam telah diakui keberadaannya dalam peraturan perundangundangan maupun dalam kehidupan masyarakat, maka hukum Islam akan berjalan seiring dengan pengembangan sistem hukum tertulis dan hukum tidak tertulis.

Pengembangan SDM adalah upaya untuk meningkatkan kemampuan tenaga kerja atau tenaga profesi untuk memenuhi kebutuhan organisasi. Upaya itu dilakukan memalui rangakaian program yang khusus dirancang oleh organisasi dengan tujuan meningkatkan pengetahuan, keterampilan dan memperbaiki sikap melalui berbagai macam aktivitas.

Metode pendekatan yang digunakan dalam pengembangan SDM adalah pendekatan proaktif (proactive approuch), yaitu pendekatan antisipatif terhadap masalah yang akan terjadi pada waktu yang akan datang (Wither, 1993:7). Namun pendekatan ini belum memasyarakat pada institusiinstitusi hukum.

Pendekatan proaktif ini sudah seharusnya mulai digunakan dalam penyusunan program-program pengembangan SDM aparatur hukum, baik untuk kalangan legislator (ahli perundang-undangan), penegak hukum, maupun untuk aparat birokrasi yang memberikan pelayanan hukum pada masyarakat. Dengan pendekatan proaktif ini kita mampu menyiapkan aparatur hukum yang sesuai dengan kebutuhan masyarakat dan pembangunan, serta cocok dengan tuntutan zaman.

Untuk memilih jenis program pengembangan dan menentukan sarana pengembangan apa yang tepat, maka terlebih dahulu perlu dii

dentifikasikan tantangan-tantangan yang dihadapi, baik tantangan dalam lingkungan internal institusi-institusi hukum, lingkungan eksternal masyarakat, dan tantangan profesionalisme.

Tantangan dalam institusi-institusi hukum adalah terbatasnya jumlah personil, terutama untuk tenaga ahli perundang-undangan, aparat kepolisian, dan kurangnya sarana dan prasarana. Tantangan ekstemal dari masyarakat adalah kurangnya kepercayaan kepada penegak hukum, merosotnya wibawa hukum, dan melembaganya budaya- budaya hedonistik dan konsumeristik dalam masyarakat. Sedangkan tantangan profesional meliputi kurangnya wawasan pemikiran dan keterampilan teknis untuk bekerja, rendahnya motivasi kerja dan penghayatan terhadap cita-cita profesi, dan rusaknya mental aparat penegak hukum.

Berdasarkan tantangan-tantangan yang dihadapi tersebut, maka pengembangan SDM aparatur hukum harus diarahkan pada pengembangan kemampuan profesional dan pembinaan mentalitas. Dengan demikian program-program pengembangan harus mengacu kepada peningkatan pengetahuan dan keterampilan kerja, penumbuhan motivasi kerja, penghayatan cita-cita profesi, dan peningkatan moralitas personal.

Program-program tersebut dapat dilaksanakan melalui sarana pendidikan dan latihan, baik berupa pendidikan formal lanjutan maupun dajam bentuk kursus-kursus pendalaman (refreshing courses). Di samping itu, dapat juga digunakan sarana rotasi dan promosi jabatan, pemindahan, konseling, dan keikutsertaàn dalam kegiatan ilmiah. 
Pengembangan SDM aparatur hukum ini belum digarap secara baik. kalaupun ada pembinaan aparatur hukum, hal itu dilakukan secara temporal (situasional) dan tidak berkesinambungan. Dan Hampir tidak pernah ada langkah bersama di antara institusiinstitusi hukum untuk memecahkan masalah pengembangan SDM ini, untuk pengembangan SDM penegak hukum kerjasama instasional ini sangat penting, kareena begitu eratnya kaitan tugas mereka.

Upaya untuk meningkatkan efisiensi dan efektivitas penegakan hukum harus dilakukan secara integratif. Efisiensi dan efektifitas penegakan hukum dipengaruhi oleh faktor-faktor internal dalam sistem hukum dan faktor-faktor eksternal dalam masyarakat. Adapun faktor-faktor internal dalam sistem hukum meliputi faktor hukum, aparat penegak hukum, organisasi penegak hukum, dan faktor prasarana. Sedangkan faktor eksternal dalam masyarakat adalah struktur sosial, kesadaran hukum masyarakat, budaya hukum, dan politik hukum penguasa.

Pendayagunaan hukum dalam pembangunan nasional adalah upaya memfungsikan hukum dalam proses pembangunan nasional untuk melakukan perubahan sosial yang sesuai dengan cita-cita konstitusi. Keberadaan dan fungsi hukum dalam proses perubahan sosial dapat dijelaskan dalam dua perspektif. Perspektif pertama memandang keberadaan dan fungsi hukum adalah mengikuti perubahan-perubahan yang terjadi dan sedapat mungkin mengesahkan perubahan-perubahan tersebut guna mempertahankan stabilitas sosial (a tool of social control). Sedangkan dalam prespektif kedua, fungsi hukum adalah sebagai alat rekayasa sosial ( $a$ tool of social engineering) guna mencapai tujuan bersama masyarakat (Soerjono Soekanto, 1980:47).

Pendayagunaan hukum dalam pembangunan nasional harus diarahkan untuk memecahkan ketimpangan sosial ekonomi yang terdapat dalam masyarakat. Hukum harus mengarahkan agar proses pembangunan ekonomi dapat menciptakan keadilansosial bagi seluruh rakyat. Dengan kata lain, hukum harus dapat mengatasi ketimpangan sosial yang bersifat struktural dalam masyarakat kita.

Guna menunjang pendayagunaan hukum untuk pemerataan pendapat dan keadilan sosial dalam masyarakat, maka dalam pembangunan legislasi harus segera dibuat UU Antimonopoli, UU Perlindungan konsumen, UU perlindungan pengusaha lemah. Dengan adanya perangkat-perangkat hukum tersebut, maka fenomena konglomerasi yang terdapat dalam. masyarakat akan dapat dibendung, dan pendistribusian hasil-hasil pembangunan akan semakin merata.

Hanya dengan pendekatan sistemik, pembangunan hukum dalam PJP II akan berhasil meningkatkan kualitas hukum, kualitas pelayanan hukum, kualitas penegakan hukum, dan kualitas hidup yang berkeadilan sosial dalam masyarakat kita.

\section{Rujukan}

H.W. Arndt, Pembangunan dan Pemerataan, LP3ES, Jakarta, 1983.

Wither, Human Resources Management, 1993.

Stewart Macauly, An Empirical View of Contract, Winsconsin Law Review, 1983.

Soerjono Sekanto, Penegakan Hukum, Rajawali, 1980. GBHN 1993

\section{Biodata}

* Salman Luthan, SH., adalah staf pengajar FH-UII. Aktif menulis diberbagai media massa. Saat ini sedang melanjutkan studi S-2 pada Fakultas Pasca Sarjana Universitas Indonesia Depok, Jakarta. 